\title{
FACTORS IN THE ETIOLOGY OF PULMONARY STENOSIS
}

\author{
BY \\ MAURICE CAMPBELL \\ From the Institute of Cardiology and the Cardiac Department, Guy's Hospital \\ Received May 24, 1962
}

In an attempt to elucidate the causes of congenital heart disease, we have made inquiries about the families of many of our patients. So far these have covered (1) 384 patients, mostly with Fallot's tetralogy, (2) 261 patients with persistent ductus arteriosus, (3) 151 patients with coarctation of the aorta, and (4) 170 patients with atrial septal defect (Polani and Campbell, 1955, 1960; Campbell and Polani, 1961a, b).

In this paper we are applying the same methods to 125 patients with pulmonary stenosis, mostly with valvular stenosis and a closed ventricular septum, but including 15 with a defect of this septum; hæmodynamic data of these 15 were discussed by Brotmacher and Campbell (1958). In 116 of them the diagnosis was confirmed by cardiac catheterization, operation, or necropsy, and often by more than one of these.

\section{Other Malformations in the Propositi}

Other cardiac malformations that appeared to be independent of the pulmonary stenosis were present in 26 cases $(21 \%)$ and are listed in Table I.

TABLE I

Other Cardiac Malformations in 26 Propositi

\begin{tabular}{c|l}
\hline $\begin{array}{c}\text { No. of cases or } \\
\text { sex and age }\end{array}$ & \multicolumn{1}{|c}{ Malformation } \\
\hline 15 cases & $\begin{array}{l}\text { Ventricular septal defect* } \\
\text { Atrial septal defect }\end{array}$ \\
\hline M 9 & $\begin{array}{l}\text { Coarctation of aorta (P59) } \\
\text { M } 21\end{array}$ \\
F 18 & $\begin{array}{l}\text { Coarctation of aorta (P73) } \\
\text { Congenital aneurysm of sinus of Valsalva (P68) } \\
\text { F } 8\end{array}$ \\
F 30 & Large patent ductus arteriosus (P88) \\
\hline
\end{tabular}

* One of these cases had also coarctation of the aorta +other malformations, and another had also a patent ductus arteriosus.

Non-cardiac malformations were present in 16 of the 125 cases and are listed in Table II. This incidence of 13 per cent compares with the 16 per cent found in a similar group by Lamy, de Grouchy, and Schweisguth (1957) and between 4 and 12 per cent found by us in other forms of congenital heart disease. 
TABLE II

Major Non-CARdiac Malformations in Propositi*

\begin{tabular}{|c|c|}
\hline Sex and age & Malformation \\
\hline F 22 & Bilateral congenital dislocation of hip (P15) \\
\hline F 6 & $\begin{array}{l}\text { Recto-vaginal fistula and defects of ribs and hemi- } \\
\text { vertebræ (P28) }\end{array}$ \\
\hline F 22 & Bilateral talipes (P39) \\
\hline F 14 & Turner's syndrome (chromatin negative) (P56) \\
\hline F 4 & Severe mental defect (P107) \\
\hline M 15 & Congenital pyloric stenosis (P110) \\
\hline M 16 & $\begin{array}{l}\text { Absence of right kidney and ureter, abnormal ribs } \\
\text { and bronchus and other malformations (P115) }\end{array}$ \\
\hline F 8 & Dwarfism (P26) \\
\hline F 12 & Arachnodactyly (P67) \\
\hline
\end{tabular}

* There were also 7 patients with less severe malformations: fused cervical vertebræ, kyphoscoliosis from hemivertebræ, spina bifida, undescended testicles, cystic disease of lung, pilo-nidal sinus, and a nævus of arm.

\section{Malformations in Sibs of Propositi}

Malformations of the Heart (Table III). There were six such examples among 282 sibs, an incidence of $2 \cdot 1$ per cent, excluding the two uncertain examples shown at the bottom of Table III. This is four times as much as would be expected by chance, and Frabricius also (1959) found an incidence of 4 per cent and Lamy et al. (1957) one of $3 \cdot 7$ per cent.

TABLE III

Six Sibs of Propositi who also had Congenital Heart Disease, generally Pulmonary Stenosis

\begin{tabular}{|c|c|c|c|c|c|}
\hline \multicolumn{3}{|c|}{ Propositus } & \multicolumn{3}{|r|}{ Sib } \\
\hline No. & $\begin{array}{l}\text { Year of birth and } \\
\text { method of diagnosis }\end{array}$ & Sex & Sex & $\begin{array}{l}\text { Year of } \\
\text { birth }\end{array}$ & Diagnosis (and method) \\
\hline $\begin{array}{l}\text { P8 } \\
\text { P51 } \\
\text { P79 } \\
\text { P104 } \\
\text { P126 }\end{array}$ & $\begin{array}{l}1931 \text { (C. Op) } \\
1944 \text { (C.) } \\
1942 \text { (C. Op.) } \\
1951(\text { Cl.) } \\
1944(\text { C. })^{*}\end{array}$ & $\begin{array}{l}\text { M } \\
\mathrm{F} \\
\mathrm{M} \\
\mathrm{M}\end{array}$ & $\left\{\begin{array}{l}\mathbf{F} \\
\mathbf{M} \\
\mathbf{M} \\
\mathbf{F} \\
\mathbf{M} \\
\mathbf{M}\end{array}\right.$ & $\begin{array}{l}1933 \\
1940 \\
1933 \\
1948 \\
1957 \\
1948\end{array}$ & $\begin{array}{l}\text { P.V.S. or aortic stenosis (Cl.)† } \\
\text { Fallot's tetralogy (Cl.) } \\
\text { Fallot's tetralogy (Op.) } \\
\text { P.V.S. (C. and P.M.) P80 } \\
\text { Fallot's tetralogy (Cl.) } \\
\text { P.V.S. and V.S.D. (Cl.) }\end{array}$ \\
\hline P5 & 1945 (C. Op.) & $\mathrm{F}$ & \multirow{2}{*}{\multicolumn{3}{|c|}{$\begin{array}{l}\text { Twin of same sex, stillborn: nothing else known } \\
\text { Presumed identical twin died at } 12 \text { days, heart not mentioned but } \\
\text { diagnosis in sister not made for many years }\end{array}$}} \\
\hline P119 & 1946 (C.)* & $\mathbf{F}$ & & & \\
\hline
\end{tabular}

C. $=$ Catheterization. Op. $=$ Operation. $\quad$ P.M. $=$ Post mortem. $\quad$ Cl. $=$ Clinical.

* These two patients were proved to have a ventricular septal defect as well as P.V.S.

† This girl and her brother (P8) were both said to have aortic stenosis when the younger brother with Fallot's tetralogy was first seen: as P8 was proved to have P.V.S., we think this was probably so with the sister also.

As with the propositi who had persistent ductus, the lesions tend to be concordant but not absolutely so. All the six sibs of the propositi were thought to have pulmonary stenosis, but three had Fallot's tetralogy and we do not know if their stenosis was valvular or infundibular. Another $\stackrel{\infty}{+}$ had simple pulmonary stenosis (concordant and both severe, though it was not severe in the younger sister when she was first seen). Another and the sib were both thought to have P.V.S. and a ventricular septal defect, but every effort to persuade the mother to allow catheterization of the second has failed. 
In the last family, there were three sibs, one with Fallot's tetralogy, one with proved pulmonary stenosis, and one whom we could not get up for examination who was said to have aortic stenosis but this was probably wrong, since it had been the diagnosis in her brother who was proved to have pulmonary stenosis. This finding with the brother has been repeated in at least two other families and agrees with our experience that two malformations in a family are most often concordant.

There were only four non-cardiac malformations reported to us, and this incidence among 282 sibs is not significant. This has also been our experience in other groups of congenital heart disease and that of Lamy et al. (1957).

\section{Malformations in Parents and Children}

We have found no example of a congenital malformation (cardiac or non-cardiac) among the parents of our propositi, nor any example of a family with as many affected members as there were in the family with atrial septal defect, reported recently (Campbell and Polani, 1961b). There is, however, one family (Table IV, P23) where four members may have been affected and Dr. Burton M. Cohen (personal communication) has informed me of a family he is reporting where, $I$ understand, a mother and several of her five children had congenital pulmonary stenosis.

We have little information about children of the propositii. Many were young and though most of the girls of suitable age who had operations have married, we have information so far about 13 children only. Among these all were normal except two-one who had a næuv that needed operation and one who died soon after birth with porencephaly. We had little information about these for our other groups but among the 72 children of patients with coarctation or atrial septal defect there were 3 with cardiac and 2 with non-cardiac malformations. The numbers are too small to be significant but there are certainly enough to make it worth continuing inquiries on these lines.

\section{MALFORMATIONS IN OTHER RelativeS}

There were 7 examples of cardiac, and 11 examples of non-cardiac malformations. As these questions were answered for 117 families, the 18 examples are probably not significant. The cardiac malformations are shown in Table IV, and the non-cardiac ones included a mongol, early death from deformity, early death from a nervous disease, hydrocephalus, and spasticity ( 3 examples), all these in first cousins; and an early operation for diaphragmatic hernia, early deaths from spinal defect and from deformity, and mental defect, all these in uncles or aunts.

TABLE IV

Cardiac Malformations in other Relatives of Propositi

\begin{tabular}{|c|c|}
\hline Relationship & Malformation \\
\hline $\begin{array}{l}\text { First cousin (P18) } \\
\text { First cousin (P93) } \\
\text { First cousin (P86) } \\
\text { First cousin (P86) } \\
\text { Father's mother and } 2 \text { aunts (P23) }\end{array}$ & $\begin{array}{l}\text { Pulmonary stenosis } \\
\text { Died, aged } 21 \text {, with morbus cœruleus } \\
\text { Died, aged } 9 \text { months, with congenital heart disease } \\
\text { Died, aged } 30 \text { months, with congenital heart disease } \\
\text { Died early, probably with pulmonary stenosis }\end{array}$ \\
\hline
\end{tabular}

\section{Consanguinity of PARENTs}

Information was available about consanguineous marriages for 112 families and in 111 there was no known relationship between the parents of our propositii, and in one family only, they were first cousins (P113). Lamy et al. (1957), however, found the parents were first cousins in 2 of their 56 families, so combining these two series would give an incidence of nearly 2 per cent which is much above the expectation in the general population $(0.4 \%$ in England: Bell, 1940, and rather higher in France). 


\section{Influence of Parental Age and Birth ORder}

The ages of the parents showed no obvious differences from what might be expected. We know the age of both in 105 pairs and the means were 29.35 years for the mother and 32.83 for the father, taking the age of each parent to the nearest month. The difference of 3.48 years between the mean paternal and maternal ages is considerably more than the figure of $2 \cdot 3$ years that was previously accepted for the general population of England and Wales, but in view of the figure of 3.2 found by Alice Stewart (personal communication) for 3751 families, it cannot be regarded as significant.

Any correlation between maternal age and a congenital malformation is often thought to show that the cause of the malformation is environmental, but equally it may be a factor that reveals a genetically determined defect. We have recently (Campbell and Polani, 1961b) given our reasons for comparing the maternal ages at the time of birth of the propositi with the ages at the birth of the other sibs, and have described the methods that we have used for separating the effects of maternal age and birth order. A series of tables is compiled that shows the number of maternities, the birth order, and the maternal age (in five-year periods) for each family. From this, a table is constructed to show the observed and expected numbers for each maternal age group and for each parity, and the sampling variances. These last figures enable one to estimate the statistical significance of any differences between the observed and expected numbers. The results are shown inTable V.

TABLE V

Comparison of 115 Patients with Pulmonary Stenosis and their 250 Normal Sibs With Respect to BiRth Order and Maternal Age

\begin{tabular}{|c|c|c|c|c|c|c|c|}
\hline \multirow{2}{*}{$\begin{array}{l}\text { Birth } \\
\text { order }\end{array}$} & \multicolumn{6}{|c|}{ Maternal age } & \multirow{2}{*}{ Total } \\
\hline & Up to 19 & $20-24$ & $25-29$ & $30-34$ & $35-39$ & 40 \& over & \\
\hline 1 st & 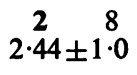 & $\begin{array}{c}15 \\
13 \cdot 00 \pm 6 \cdot 9\end{array}$ & $\begin{array}{cr}21 & 45 \\
21 \cdot 60 & 48 \cdot 8\end{array}$ & $\begin{array}{cr}7 & 14 \\
7 \cdot 91 & 14 \cdot 6\end{array}$ & ${ }_{2 \cdot 0}^{2} \pm 0^{2}$ & $\mathbf{0}$ & $\begin{array}{cc}47 & 106 \\
46 \cdot 95 & \pm 19 \cdot 3\end{array}$ \\
\hline 2nd & $\begin{array}{cc}0 & 2 \\
0 \cdot 29 & \pm 0 \cdot 2\end{array}$ & $\begin{array}{cr}2 & 17 \\
4 \cdot 82 & 3 \cdot 0\end{array}$ & $\begin{array}{l}14 \\
12 \cdot 16 \pm 7 \cdot 5\end{array}$ & $\underset{11 \cdot 35}{12} \begin{array}{r}27 \\
12 \cdot 3\end{array}$ & $\begin{array}{c}5 \\
3 \cdot 91\end{array} 2^{9} \cdot 1^{9}$ & $\underset{0 \cdot 50}{0} \underset{0}{1} \cdot 3$ & $\begin{array}{c}33 \\
33 \cdot 03 \pm 19 \cdot 4\end{array}$ \\
\hline $3 r d$ & & $\begin{array}{c}1 \\
1 \cdot 15 \pm 1 \cdot 0^{8}\end{array}$ & $\begin{array}{c}4 \\
6 \cdot 10\end{array} \stackrel{20}{20}$ & $\begin{array}{cr}3 & 18 \\
5 \cdot 30 \pm 3 \cdot 2\end{array}$ & $\begin{array}{c}2 \\
3 \cdot 68 \pm 2 \cdot 6\end{array}$ & $\underset{0 \cdot 33}{1} \underset{0 \cdot 2}{1}$ & $\begin{array}{lc}11 & 58 \\
16 \cdot 56 \pm 10 \cdot 8\end{array}$ \\
\hline 4th & & $\begin{array}{c}1 \\
0 \cdot 70 \pm 0 \cdot 6\end{array}$ & $\stackrel{1}{1 \cdot 40} \pm 1 \cdot{ }^{7}$ & $\stackrel{2}{2 \cdot 01} \pm 1 \cdot 9$ & $\begin{array}{c}5 \\
3 \cdot 20 \pm 2 \cdot 3\end{array}$ & $\underset{1}{1} \stackrel{3}{3}$ & $\begin{array}{l}10 \\
8 \cdot 31 \\
\mathbf{3} \cdot 6 \cdot 2\end{array}$ \\
\hline 5 th & & ${ }_{0 \cdot 24}^{1} \pm 0 \cdot 2^{3}$ & $\mathbb{0}_{0 \cdot 46 \pm 0 \cdot 4}^{3}$ & ${\stackrel{4}{1 \cdot 49} \pm 1 \cdot 2^{8}}^{8}$ & $\underset{2 \cdot 13}{1} \stackrel{10}{10}$ & $\underset{0.50}{0} \underset{0}{2} \cdot 4$ & $\begin{array}{cr}7 & 26 \\
4 \cdot 82 & 26 \\
\end{array}$ \\
\hline 6th & & $\begin{array}{cr}0 & 2 \\
0 \cdot 17 & 2 \\
0 & 0 \cdot 1\end{array}$ & $\begin{array}{cr}0 & 4 \\
0 \cdot 45 & 4 \\
\end{array}$ & $\stackrel{0}{0 \cdot 28} \pm 0 \cdot 2^{2}$ & $\cdot \stackrel{1}{0 \cdot 70} \pm 0.5$ & $\underset{0 \cdot 14}{1} \begin{array}{c}1 \\
0 \cdot 1\end{array}$ & $\begin{array}{cr}2 & 13 \\
1 \cdot 74 & 1 \cdot 5\end{array}$ \\
\hline 7th & & & $\begin{array}{l}1 \\
0 \cdot 46 \pm 0.4\end{array}$ & & $\stackrel{1}{0 \cdot 25} \pm 0 \cdot 2^{2}$ & $\begin{array}{cc}1 & 3 \\
0 \cdot 53 & \pm 0 \cdot 4\end{array}$ & $\begin{array}{cc}3 & 10 \\
1 \cdot 24 \pm 1 \cdot 0\end{array}$ \\
\hline 8 th & & & $\begin{array}{c}0 \\
0.07\end{array} \pm 0.1$ & $\begin{array}{c}0 \\
0 \cdot 21 \pm 0 \cdot 2\end{array}$ & $\begin{array}{c}0 \\
0 \cdot 11\end{array} \pm 0 \cdot 1$ & $\underset{0}{0} \stackrel{2}{2}$ & $\stackrel{0}{0.78} \pm 0.7^{6}$ \\
\hline $\begin{array}{c}\text { 9th } \\
\text { and after }\end{array}$ & & & ${\stackrel{0}{0 \cdot 24} \pm 0 \cdot 2^{3}}^{2}$ & $\mathrm{0}_{0 \cdot 21}^{0} \pm 0 \cdot 2^{3}$ & ${ }_{0 \cdot 62}^{1} \pm 0.5^{8}$ & $\begin{array}{cc}1 & 3 \\
0 \cdot 29 & \pm 0 \cdot 2\end{array}$ & $\begin{array}{cr}2 & 17 \\
1 \cdot 36 & 1 \cdot 2\end{array}$ \\
\hline Total & $\begin{array}{cc}2 & 10 \\
2 \cdot 73 & \pm 1 \cdot 3\end{array}$ & $\begin{array}{cc}20 & 73 \\
20 \cdot 08 & \pm 11 \cdot 8\end{array}$ & $\begin{array}{cc}42 & 124 \\
42 \cdot 94 & 122 \cdot 7\end{array}$ & $\begin{array}{cc}28 & 83 \\
28 \cdot 76 & \pm 15 \cdot 4\end{array}$ & $\begin{array}{c}18 \\
16 \cdot 60 \pm 10 \cdot 1\end{array}$ & $\begin{array}{cc}5 & 16 \\
3 \cdot 68 \pm 2 \cdot 6\end{array}$ & 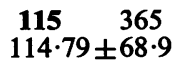 \\
\hline
\end{tabular}

The three sets of figures in each column represent (1) the number of affected children (bold figures), (2) the total number of children at this maternal age and birth order, and (3) the expected number of affected children with their sampling variance (below). 
Neither maternal age nor birth order are proved to have a significant influence on the production of pulmonary stenosis. There is, however, an excess of fourth and later children with pulmonary stenosis born to mothers of all ages (24 instead of the expected 18.3) balanced by a deficiency of third-born children, the first and second being almost exactly what would be expected. There is a much smaller excess of affected children of all birth ranks born to mothers aged 35 years or over (23 instead of $20 \cdot 3$ ), balanced by small deficiencies in those born to younger mothers.

Neither of these differences is statistically significant, though the difference between the observed and expected numbers of fourth and later children with pulmonary stenosis born to mothers of all ages $(5 \cdot 7)$, and still more those born to mothers of 35 or over (13 instead of $9 \cdot 8)$, is not very much below the level of significance, twice the square root of the sampling variance.

\section{SeX Distribution}

There does not seem to be any difference between the sexes in the incidence of pulmonary stenosis. There was a small excess of girls and women in these 125 cases but in an earlier series (Campbell, 1954) it was more nearly equal (male 47, female 53) and Wood (1956) also finds it equal. Nor have we any evidence of a differential sex mortality after birth, though our experience of infants under 5 is limited, since the excess of girls under 10 is just the same as the excess of women over 30 years of age.

\section{Birth Weights of Patients with Pulmonary Stenosis}

We have found nothing remarkable about the mean or the distribution of the birth weights of our patients with pulmonary stenosis. We have excluded twins because of their lighter weights and have made the comparison with the normal sibs of the propositi, because this eliminates any possible influence of social or economic status. The mean values are shown in Table VI.

TABLE VI

Mean Birth Weights of 88 Patients with Pulmonary Stenosis and their 176 Normal Sibs

\begin{tabular}{|c|c|c|c|c|c|}
\hline & & \multicolumn{2}{|c|}{ Boys } & \multicolumn{2}{|c|}{ Girls } \\
\hline & & With P.V.S. & Sibs & With P.V.S. & Sibs \\
\hline $\begin{array}{l}\text { Total number } . . \\
\text { Mean weight }(\mathrm{lb} .) \pm S . . . \\
\text { Standard deviation } \\
\text { Mean weight }(\mathrm{kg} .)\end{array}$ & $\begin{array}{l}\cdots \\
\cdots \\
\cdots\end{array}$ & $\begin{array}{c}40 \\
7 \cdot 40 \pm 0 \cdot 26 \\
1 \cdot 65 \\
3 \cdot 36 \mathrm{~kg}\end{array}$ & $\begin{array}{c}94 \\
7 \cdot 57 \pm 0 \cdot 13 \\
1 \cdot 26 \\
3 \cdot 44 \mathrm{~kg}\end{array}$ & $\begin{array}{c}48 \\
7 \cdot 13 \pm 0 \cdot 22 \\
1 \cdot 52 \\
3 \cdot 24 \mathrm{~kg}\end{array}$ & $\begin{array}{c}82 \\
7 \cdot 00 \pm 0 \cdot 18 \\
1 \cdot 63 \\
3 \cdot 18 \mathrm{~kg}\end{array}$ \\
\hline
\end{tabular}

\section{The Seasonal InCidence of BirThS}

It might seem unreasonable to think of any influence of seasons on the number of births of subjects with pulmonary stenosis, but this is found in some forms of congenital heart disease. Our figures have shown that girls with persistent ductus are born more frequently from August to October and that boys with coarctation of the aorta are born more frequently from December to July.

The quarterly figures for the boys with pulmonary stenosis varied widely from 19 for July to September to 6 births for April to June (Table VII). The quarterly figures for the girls varied rather less: the largest number, 22, were born in the first quarter and the least, 12 each, in the second and fourth quarters. The figures for the normal sibs varied much less widely (Table VII). Our figures are not large enough to make sure that these differences are significant. The monthly figures certainly are not, but we have shown the numbers for each month, and for boys and girls separately, in Table VIII, so that they can be added to data collected from other sources. 
TABLE VII

Quarterly Incidence of Births of Patients with Pulmonary Stenosis and their Normal Sibs

\begin{tabular}{|c|c|c|c|c|c|c|}
\hline & & & $\begin{array}{c}\text { January } \\
\text { to } \\
\text { March }\end{array}$ & $\begin{array}{l}\text { April } \\
\text { to } \\
\text { June }\end{array}$ & $\begin{array}{c}\text { July } \\
\text { to } \\
\text { September }\end{array}$ & $\begin{array}{c}\text { October } \\
\text { to } \\
\text { December }\end{array}$ \\
\hline \multicolumn{7}{|c|}{ With pulmonary stenosis } \\
\hline $\begin{array}{l}\text { Boys (51) .. } \\
\text { Girls (64) . } \\
\text { Total (115) }\end{array}$ & $\begin{array}{l}\ldots \\
\cdots \\
\cdots\end{array}$ & $\begin{array}{l}\ldots \\
\cdots \\
\cdots\end{array}$ & $\begin{array}{l}14 \\
22 \\
36\end{array}$ & $\begin{array}{r}6 \\
12 \\
18\end{array}$ & $\begin{array}{l}19 \\
18 \\
37\end{array}$ & $\begin{array}{l}12 \\
12 \\
24\end{array}$ \\
\hline \multicolumn{7}{|l|}{ Normal sibs } \\
\hline $\begin{array}{l}\text { Boys }(105) \\
\text { Girls }(102) \\
\text { Total (207) }\end{array}$ & $\begin{array}{l}\ldots \\
\ldots \\
\ldots\end{array}$ & $\begin{array}{l}\ldots \\
\cdots \\
\cdots\end{array}$ & $\begin{array}{l}29 \\
31 \\
60\end{array}$ & $\begin{array}{l}30 \\
21 \\
51\end{array}$ & $\begin{array}{l}27 \\
27 \\
54\end{array}$ & $\begin{array}{l}19 \\
23 \\
42\end{array}$ \\
\hline
\end{tabular}

The births of our patients with pulmonary stenosis were spread over a wide period from 19171951, but 93 per cent of them were between 1923 and 1949. Because of this wide spread, we have compared the season of births with that of their normal sibs. Up to 1939 the number of normal births was a little greater in the second quarter of the year, though before 1923 it was sometimes greater in the first than in the second quarter. From 1940 onwards the seasonal incidence of births was unusual because of the disturbed conditions during and after the war. We, therefore, analysed our figures separately for the four periods 1901-1922, 1923-39, 1940-49, and 1950 onwards, but there were so few in the first and fourth of these periods that we combined them with the second and third respectively, and have shown only the numbers born in 1939 and before, and in 1940 and after (the lower figures in Table VIII).

TABLE VIII

The Monthly Incidence of Births of Patients with Pulmonary Stenosis and their Normal Sibs

\begin{tabular}{|c|c|c|c|c|c|c|c|c|c|c|c|c|}
\hline & Jan. & Feb. & Mar. & Apr. & May & June & July & Aug. & Sept. & Oct. & Nov. & Dec. \\
\hline $\begin{array}{l}\text { Boys with } \\
\text { P.S. (51) . } \\
\text { Girls with } \\
\text { P.S. (64) .. }\end{array}$ & $\begin{array}{c}3 \\
1+2 \\
5 \\
2+3\end{array}$ & $\begin{array}{c}6 \\
5+1 \\
9 \\
5+4\end{array}$ & $\begin{array}{c}5 \\
4+1 \\
\\
8 \\
4+4\end{array}$ & $\begin{array}{c}1 \\
0+1 \\
4 \\
4 \\
2+2\end{array}$ & $\begin{array}{c}3 \\
1+2 \\
5 \\
3+2\end{array}$ & $\begin{array}{c}2 \\
2+0 \\
3 \\
1+2\end{array}$ & $\begin{array}{c}5 \\
2+3 \\
\\
7 \\
1+6\end{array}$ & $\begin{array}{c}8 \\
4+4 \\
5 \\
4+1\end{array}$ & $\begin{array}{c}6 \\
1+5 \\
6 \\
6 \\
5+1\end{array}$ & $\begin{array}{c}4 \\
2+2 \\
2 \\
1+1\end{array}$ & $\begin{array}{c}4 \\
2+2 \\
2 \\
2+0\end{array}$ & $\begin{array}{c}4 \\
3+1 \\
8 \\
6+2\end{array}$ \\
\hline $\begin{array}{l}\text { Normal } \\
\text { boys (105) } \\
\text { Normal } \\
\text { girls (107) }\end{array}$ & $\begin{array}{c}8 \\
4+4 \\
\\
14 \\
7+7\end{array}$ & $\begin{array}{c}8 \\
5+3 \\
7 \\
2+5\end{array}$ & $\begin{array}{c}13 \\
7+6 \\
\\
10 \\
1+9\end{array}$ & $\begin{array}{c}12 \\
3+9 \\
7 \\
6+1\end{array}$ & $\begin{array}{c}9 \\
4+5 \\
6 \\
4+2\end{array}$ & $\begin{array}{c}9 \\
5+4 \\
8 \\
7+1\end{array}$ & $\begin{array}{c}11 \\
7+4 \\
10 \\
7+3\end{array}$ & $\begin{array}{c}7 \\
5+2 \\
6 \\
6+3\end{array}$ & $\begin{array}{c}9 \\
4+5 \\
11 \\
6+5\end{array}$ & $\begin{array}{c}5 \\
3+2 \\
7 \\
4+3\end{array}$ & $\begin{array}{c}8 \\
4+4 \\
\\
12 \\
6+6\end{array}$ & $\begin{array}{c}6 \\
1+5 \\
4 \\
2+2\end{array}$ \\
\hline
\end{tabular}

The smaller figures below refer to births in the two periods, up to 1939 and 1940 and after. For the propositi the range was 1917-51 and for their sibs 1901-58: in both groups the majority were born between 1923 and 1949.

\section{ENVIRONMENTAL FACTORS}

Exposure to Radiation. We asked whether the mother had undergone radiographical examination during the relevant pregnancy in case this might have any influence in producing a malformation of the heart of the child. The answers did not give us any useful information. The question was badly designed and it might have been more useful to ask about all abdominal X-ray examinations at any time before the birth of the child in question. Of the 86 mothers of propositi with pulmonary 
stenosis who answered the question, 79 had not, and only 7 had undergone such an examination, sometimes (perhaps generally) shortly before the confinement.

One mother, however, wrote that she had been given a course of deep X-ray therapy (details not known) for asthma: this had been completed two years before the conception of her son, who was born with coarctation as well as pulmonary stenosis.

Twin pregnancies do not seem to have any influence except that one of a pair of monozygotic twins, and one only, is a little more likely to be born with a malformation of the heart (Campbell, 1961).

Other Environmental Factors. During the first three months of these 125 pregnancies, there were 12 episodes that might have some significance. The first two were almost certainly so, and perhaps the third, but the others were more doubtful. Their significance, if any, cannot be settled by a retrospective study, but only a prospective study where the decision as to whether the episode should be recorded or not has been taken before the result of the pregnancy is known. Such a prospective study seems well worth making but it would have to be on a fairly large scale.

(1) Measles during third month of pregnancy (P44).

(2) Vaccination as a smallpox contact two months after conception (P8).

(3) Severe electric shock during second month (P100).

(4) "Ulcerative colitis" during early pregnancy (P74).

(5) Corpus luteum injections, because of previous miscarriage (P52).

(6) Injections after hæmorrhage during third month (P20).

(7) Conception during breakdown in health after miscarriage (P124).

(8) Exposure to heavy bombing during second month of pregnancy (P56).

(9) Anxiety from air raids at time of conception and after (P122).

(10) Exceptional anxiety during early pregnancy (P63).

(11) Severe vomiting during first three months of pregnancy (P4).

(12) Severe vomiting through most of pregnancy and biliary colic (P115).

\section{Summary AND CoNClusions}

We have made inquiries about the families of 125 patients with pulmonary stenosis in an attempt to find genetic or environmental factors that might help to explain its ætiology. Many of the propositi-21 per cent and still 9 per cent if those with ventricular septal defect were omitted-had other malformations of the heart, even though subjects with Fallot's tetralogy were excluded. Noncardiac malformations also were present in nearly 13 per cent.

A cardiac malformation, nearly always pulmonary stenosis, was present in $2 \cdot 2$ per cent of the sibs of the propositi, much more than would be expected by chance. This seemed to be the case also for the small number of children, but not for the parents, of the propositi.

There is some evidence that the number of first-cousin marriages between the parents is more than would be expected by chance.

There were more fourth and later children with pulmonary stenosis born to mothers of all ages, and especially to those aged 35 and over, than would be expected (24 instead of 18.3). In neither group was the excess large enough to prove that it was significant. Mean paternal age exceeded mean maternal age by 3.48 years, the largest difference we have found in our groups of congenital heart disease.

There is no great difference in the sex incidence of pulmonary stenosis. The boys with pulmonary stenosis were slightly lighter than their normal brothers, and the girls were slightly heavier than their normal sisters, but neither difference was significant.

More boys with pulmonary stenosis were born in the July to September quarter-three times as many as in April to June. The differences for the girls were less though nearly half were born between December and March. These findings need confirmation from larger numbers. 
I would have liked to add the name of Professor P. E. Polani as a joint author, but he thought his share of the work had gradually diminished in our series of papers till this was no longer right. This does, however, give me the opportunity of thanking him publicly for all I have learnt from him-not only about the use of some statistical methods but also about many aspects of normal children.

\section{REFERENCES}

Bell, Julia (1940). A determination of the consanguinity rate in the general hospital population of England and Wales. Ann. Eugen. (Lond.), 10, 370.

Brotmacher, L., and Campbell, M. (1958). Ventricular septal defect with pulmonary stenosis. Brit. Heart J., $20,381$. Campbell, M. (1954). Simple pulmonary stenosis. Pulmonary valvular stenosis with a closed ventricular septum. Brit. Heart J., 16, 273.

(1961). Twins and congenital heart disease. Acta Genet. med. (Roma), 10, 443.

- and Polani, P. E. (1961a). The ætiology of coarctation of the aorta. Lancet, 1, 463. (1961b). Factors in the ætiology of atrial septal defect. Brit. Heart J., 23, 477.

Fabricius, J. (1959). Isolated Pulmonary Stenosis. Munksgaard, Copenhagen.

Lamy, M., de Grouchy, J., and Schweisguth, O. (1957). Genetic and non-genetic factors in the ætiology of congenital heart disease: a study of 1188 cases. Amer. J. hum. Genet., 9, 17.

Polani, P. E., and Campbell, M. (1955). An ætiological study of congenital heart disease. Ann. hum. Genet., 19, 209.

(1960). Factors in the causation of persistent ductus arteriosus. Ann. hum. Genet., 24, 343.

Wood, P. (1956). Diseases of the Heart and Circulation, 2nd ed. Eyre and Spottiswoode, London. 